\title{
Critical Insights on The Haryana Region's Social, Cultural, And Economic Conditions During the Mughal Period
}

\author{
Mamta Rani ${ }^{1}$, Dr. Altaf Khan ${ }^{2}$ \\ ${ }^{1}$ Research Scholar, Department of History, Madhav University, Rajasthan, India \\ ${ }^{2}$ Research Supervisor, Department of History, Madhav University, Rajasthan, India
}

\begin{abstract}
Haryana has made a significant historical contribution to the socioeconomic and religious aspects of the country's people's lives. During the Sultanate and Mughal periods, the Haryana region gained strategic importance in terms of trade and defense. "Babur (reigned 1526-1530), a Central Asian king descended from the Turco-Mongol conqueror Timur (creator of the Timurid Empire) on his father's side and Genghis Khan on his mother's side, formed the Mughal Empire". The purpose of this study is to relate the socioeconomic realities of the Haryana region during the latter Mughal period in an impartial and scientific manner (1707-1857). The purpose of this study is to relate the dynamics of socioeconomic and other elements of life of the people of Haryana during the later Mughal period in an impartial and scientific manner (1707-1857). This period, which is a sub-period of Mughal history, was chosen for the purpose of our research for a variety of reasons. This was an interesting time marked by upheaval, confusion, and volatility.
\end{abstract}

Keywords : - Mughal, Social, Cultural, Political, Regions

\section{INTRODUCTION}

Due to the bifurcation of the former Punjab state, Haryana became an autonomous political entity on November 1, 1966. It is one of the smallest states in the Indian Union, notwithstanding its historical significance.

In ancient times, the Mahabharata was fought at Kurukshetra, and three battles of Panipat, which dramatically transformed India's fortunes, were fought in Haryana. This is the location where Lord Krishna delivered the Bhagvadgita message to the entire world's humanity. On the banks of the sacred river Sarasvati, which originally flowed through the region, saints and seers meditated and wrote famous epics, scriptures, and treatises. Haryana has made a significant historical contribution to the socioeconomic and religious aspects of the country's people's lives.

Despite the territory's strategic location and importance, the region and its history have been neglected and muddled. It did not receive the attention that it deserved from historians.

During the Sultanate and Mughal periods, the Haryana region gained strategic importance in terms of trade and defense. In ancient times, the Mahabharata was fought at Kurukshetra, and three 
battles of Panipat, which dramatically transformed India's fortunes, were fought in Haryana. This is the location where Lord Krishna delivered the Bhagvadgita message to the entire world's humanity. On the banks of the sacred river Sarasvati, which originally flowed through the region, saints and seers meditated and wrote famous epics, scriptures, and treatises.

Haryana has made a significant historical contribution to the socioeconomic and religious aspects of the country's people's lives. The sacred country and its stalwart people have a long and illustrious history as well as mythological importance. It had an even greater impact on Indian history since it was so close to Delhi, the most important city in the country and a seat of power for monarchs and rulers of all colors since ancient times. Republics and dynasties have risen and fallen throughout the region. In fact, Haryana's status in the country's polity was reduced to that of a 'heart' in one's body.

The purpose of this study is to relate the socioeconomic realities of the Haryana region during the latter Mughal period in an impartial and scientific manner (1707-1857).

\section{HARYANA}

Following the uprising of 1857, the Haryana region was allied with Punjab in 1858 as a kind of punishment. Throughout these years, the Haryana region has been mostly ignored. Even after India's independence in 1947, the Punjab administration did not devote enough attention to the province's growth. On November 1, 1966, the Punjab Reorganization Act separated Haryana out of Punjab, making it the Indian Union's sixteenth state. This fulfilled a long-held demand of both groups, the Sikhs and the Hindus. This is how Haryana came to be.
Haryana is one of the smallest states in the Indian Union, covering 44,212 square kilometers. The state is located between $27^{\circ} .39^{\prime}$ and $30^{\circ} .55 .5^{\prime}$ north latitude and $74^{\circ} .27 .8^{\prime}$ and $77^{\circ}$. 36.5' east longitude in India's northwestern region. Several states surround the state. Himachal Pradesh, in the north, is a neighboring state. Punjab is located in the west, Rajasthan is located in the south, and Uttar Pradesh is located in the east. Delhi is located in the state's east-south direction.

Haryana has a wide range of physical characteristics. The state can be divided into two sections: the subHimalayan tract and the Indo Gangetic plain.

Since ancient times, various rivers and rivulets have nourished the Haryana region, which is part of the Indo-Gangetic divide. These rivers have undoubtedly played an important role in Haryana's socioeconomic, cultural, and religious life.

Haryana's climate is distinctly continental for the majority of the year, with scorching summers and very frigid winters. In the months of May and June, the average maximum temperature reaches $49^{\circ} \mathrm{C}$. In the months of December and January, the temperature descends below freezing, with severe frost.

The Haryana region was once covered with deep green forests, according to ancient and medieval accounts. Haryana's flora and animals were once abundant due to the state's extensive and dense forests. Trees, plants, and bushes of all kinds grew in various sections of Haryana.

\section{HISTORY OF MUGAL PERIOD}

"Babur (reigned 1526-1530), a Central Asian king descended from the Turco-Mongol conqueror Timur (creator of the Timurid Empire) on his father's side and Genghis Khan on his mother's side, formed the Mughal Empire". 
The purpose of this study is to relate the dynamics of socioeconomic and other elements of life of the people of Haryana during the later Mughal period in an impartial and scientific manner (1707-1857). This period, which is a sub-period of Mughal history, was chosen for the purpose of our research for a variety of reasons. This was an interesting time marked by upheaval, confusion, and volatility.

This was the time when the people of this region were engulfed in wars and suffered greatly at the hands of rulers and foreign invaders such as Nadir Shah and Ahmad Shah Abdali. The time also saw the end of the Mughal Empire and the development and dominance of British control in the Haryana region. Tocal forces such as the Jats, Ahirs, Sikhs, Rohillas, and Marathas were all fighting for control in the region, making the situation highly unstable during this time. Several feudal chiefs, nawabs, rajas, and feudatories attempted to establish their own independent and autonomous power and principality in various portions of Haryana. Although neither wholly new or drastically different from the prior age, social structure and culture were continually under strain and pressure as a result of the society's unsettled situations and instability. Whereas later Mughal economic policies were risky, British policies were exploitative, based on the colonial/commercial mode of production. All of these events had a significant impact on the socioeconomic fabric of the region.

\section{ECONOMY}

"During the Mughal Empire, India's economy was huge and rich (Schmidt, 2015). During the Mughal era, India's gross domestic product (GDP) was estimated to represent $22 \%$ of the global economy in 1600 , making it the world's second largest economy after Ming China but greater than Europe. By 1700, Mughal India's GDP had climbed to $24 \%$ of global GDP, making it the world's largest economy, surpassing both Qing China and Western Europe (Maddison, 2003). Until the 18th century, the Mughal empire produced nearly $25 \%$ of the world's industrial output
(Williamson \& Clingingsmith). Under the Mughal Empire, India's GDP grew at a greater rate than it had in the 1,500 years preceding the Mughal Empire (Maddison, 2003). The economy of Mughal India has been regarded as a sort of proto-industrialization, similar to that of Western Europe before to the Industrial Revolution in the 18th century (Lex and Els, 2010)". (https://en.wikipedia.org/wiki/Mughal Empire) In ancient and medieval periods, the economic conditions of the people of Haryana were, on the whole, satisfactory1. They had plenty to eat and yet had plenty left over. However, as time passed, the condition deteriorated, and it became horrible during the course of our research. This was mostly owing to periodic riots and exploitative colonial authority, among other things. According to all accounts, this was the most ignominious moment in Haryana's history, as all negative forces wreaked havoc on the region, causing terrible political unrest and systematic economic exploitation of the people, leading to poverty and misery.

Haryana's economy, like that of the rest of the country, was primarily agrarian. More than $90 \%$ of the inhabitants lived in villages and had some sort of connection to the land, either directly or indirectly. Despite the fact that the region's agricultural produce, including food grains and non-food crops, was produced by an overwhelming majority of the population, it was done in appalling conditions. (https://cdnbbsr.s3waas.gov.in).

\section{SOCIAL CONDITION}

Starting with the fact that Mughal society and cultural practices were neither totally new nor fundamentally distinct from those of preceding or following eras, it is necessary to realize that as a whole, Indian culture, of which Haryana is a part, has remained remarkably stable over time, with only minor variations in the finer details over time. According to several historians, Haryana's history was upheaved throughout the 18th and early half of the 19th centuries. The gradual and 
ultimate collapse of the Mughal Empire, their loss of authority, debasement and British exploitation practices all distinguished this period of history. At that time, the world was through major upheaval, social instability, and economic decline. As a result, social conditions are now depicted in terms of social institutions like the family system, marriage, village, khap and tapas, caste system and caste organization, caste impact and the position of women in society, as well as folk arts and culture, education, literature and language.

(https://ncert.nic.in/textbook/pdf/gess104.pdf).

During the research period, a Hindu family in Haryana comprised of three generations and multiple collaterals living under one roof.

"Marriage has long been the most prominent social institution in Haryana, as it has been across India. Inter-caste marriages and liaisons were considered illegal, and the state intervened. Marriage to someone from an unknown caste was not permitted".

In Haryana, villages formed the most basic and longlasting social structure unit. In the year 1855, Haryana had a total of 3875 towns and villages. We don't know much about how these settlements came to be, but we do know that they existed thousands of years ago during the Chalcolitic period. "Thapa is another institution that arose when a village's residents found it inconvenient to live together. Then a segment of the community would establish a new village, and the process would repeat itself, resulting in a tract with a cluster of villages originating from a single parent village". Sarvakhapa was typically made up of multiple thapas and Sarvakhapas from different Khapas. They met on a regular basis to decide on issues of common concern to their people.

\section{POLITICAL HISTORY}

Haryana's history during the Mughal Empire was highly interesting. Haryana, located between Lahore and Delhi, was the site of many conflicts during the
Mughal period. Babur established the Mughal Empire in India in the battlefield of Panipat in 1526.

The Mughal Empire faced major troubles on all fronts with the death of Aurangzeb in March 1707, at the age of 88. The Mughal Empire was weakened as a result of the succession conflict between his three sons. After Aurangzeb, there were fourteen Mughal emperors, the last of whom was Bahadur Shah Zafar (see chart). Several of them simply served as the Mughal Empire's nominal ruler. The majority of them were apathetic, dissolute, and inept dictators incapable of inspiring either terror or respect. They were continually preoccupied with their affluence, intrigues, and luxuries, doing nothing to address the problems that had crept into the Mughal polity. The collapse of the Mughal Empire and its eventual fall had ramifications in Haryana, as well as the rest of India. Then there was the Mughal and subsequently the British persecution of Hindus and repressive measures in the region throughout the time period under consideration ("https://en.wikipedia.org/wiki/Mughal war of succession, 1707").

During the latter Mughal Empire, there was a lot of evidence of a systematic and purposeful policy towards Hindus. The British power that arose during this time period continued to subjugate the Hindus and Muslims of the region. Failed economic policies, along with periodic famines, long-term conflicts, and repressions, resulted in widespread misery, poverty, and insolvency among the people.

\section{CONCLUSION}

To summarize, the latter Mughal period can be described as a long period of socio-economic instability and unrest. This was the saddest and most horrible moment in Haryana's history. Haryanvis faced enormous deprivation, misery, tyranny, helplessness, brutal exploitation, agony, and outrage during this period of turmoil, social, and severe 
economic upheaval, with little quick hope of redemption. Both the Mughals and the British were unconcerned about the people of this region. They went so far as to try to tear the social fabric apart and resorted to indiscriminate resource exploitation. The main distinction was that, whereas the Mughal rulers attempted to Indianize themselves, the British maintained a barrier between themselves and the locals, i.e., a foreign king and Indian subjects. Communal based agrarian relations are class ties between the people and the governing class. Local individuals, such as Jats, Ahirs, Sikhs, Muslims, and people from other areas of the country, such as Marathas and Rohillas, as well as foreign invaders and Britishers, all played their roles according to their judgment, intrigues, ambition, greed, luxury, and aggrandizement. During the one hundred and fifty years covered by our study, the region continued to suffer and groan.

\section{REFERENCES}

[1]. https://en.wikipedia.org/wiki/Mughal_Empire

[2]. https://en.wikipedia.org/wiki/Mughal_war_of_s uccession_(1707)

[3]. https://ncert.nic.in/textbook/pdf/gess104.pdf

[4]. https://shodhganga.inflibnet.ac.in/bitstream/106 03/117012/12/12_chapter\%206.pdf

[5]. https://shodhganga.inflibnet.ac.in/bitstream/106 03/117012/7/07_chapter\%201.pdf

[6]. https://shodhganga.inflibnet.ac.in/bitstream/106 03/117012/8/08_chapter\%202.pdf

[7]. Jeffrey G. Williamson \& David Clingingsmith, India's Deindustrialization in the 18th and 19th Centuries, Global Economic History Network, London School of Economics

[8]. Lex Heerma van Voss; Els Hiemstra-Kuperus; Elise van Nederveen Meerkerk (2010). "The Long Globalization and Textile Producers in India". The Ashgate Companion to the History of Textile Workers, 1650-2000. Ashgate Publishing. p. 255. ISBN 978-0754664284.
[9]. Maddison, Angus (2003). Development Centre Studies The World Economy Historical Statistics: Historical Statistics. OECD Publishing. pp. 256-. ISBN 978-92-64-10414-3.

[10]. Schmidt, Karl J. (2015). An Atlas and Survey of South Asian History. Routledge. pp. 100-. ISBN 978-1-317-47681-8.

\section{Cite this Article}

Mamta Rani, Dr. Altaf Khan, "Critical Insights on The Haryana Region's Social, Cultural, And Economic Conditions During the Mughal Period", International Journal of Scientific Research in Science and Technology (IJSRST), Online ISSN : 2395-602X, Print ISSN : 2395-6011, Volume 4 Issue 7, pp. 1409-1413, March-April 2018. Available at doi $\quad$ : https://doi.org/10.32628/IJSRST218296 Journal URL : https://ijsrst.com/IJSRST218296 